\title{
Internal Bacterial Flora of Solid Uterine Cervical Cancer
}

\author{
Hiroshige MIKAMO, Koji IZUMI, Kunihiko ITO, Kunitomo WATANABE*, \\ Kazue UENO* and Teruhiko TAMAYA \\ Department of Obstetrics and Gynecology, School of Medicine, Gifu University, Gifu, Japan \\ *Institute of Anaerobic Bacteriology, School of Medicine, Gifu University, Gifu, Japan \\ (Received: April 22, 1993) \\ (Accepted: July 13, 1993) \\ Key words: uterine cervical cancer, uterine cervical cancer, aerobic bacteria, \\ anaerobic bacteria
}

\begin{abstract}
Twenty-five patients with uterine cervical cancer (Two cases stage 0 ; four cases stage Ia; five cases stage Ib; one case stage IIa; ten cases stage IIb; two cases stage IIIa; one case stage IVa) served as the subjects. The bacterial flora inside the cervical cancers was investigated using the optimal technique. There was mixed abnormal aerobic and anaerobic bacterial flora in all subjects.

The average number of bacterial species isolated from inside the cervical cancers was 6.3.

The predominant bacteria isolated were the aerobes, Staphylococcus haemolyticus, Streptococcus agalactiae, Escherichia coli and Gardnerella vaginalis, and Prevotella bivia. As the stages of cervical cancer progressed, G. vaginalis, B. distasonis and $P$. bivia were detected at higher rates and higher counts than other bacteria.

These findings suggest that there is a relationship between $G$. vaginalis, B. distasonis and $P$. bivia and the onset and growth of cervical cancer.

\section{Introduction}

We investigated abnormal bacterial flora inside solid uterine cervical cancers in connection with the onset and growth of the cancer and postoperative antimicrobial chemotherapy. There have been reports of abnormal bacterial flora in the vagina and the cervix in uterine cervical cancer ${ }^{1}$, but no investigations of bacterial flora inside uterine cervical cancer had yet been performed.

Accordingly, we investigated the bacterial flora inside solid uterine cervical cancers using the optimal methods.

\section{Materials and Methods}

\section{Subjects}

Twenty-five surgical patients with a diagnosis of stage 0 , Ia, Ib, IIa, IIb, IIIa or IVa of uterine cervical cancer were studied. Their age ranged from 38 to 78 years, and the mean age was 58.0 years. All patients underwent hysterectomy in the Department of Obstetrics and Gynecology of the School of Medicine, Gifu University, between June 1990 and December 1992. The histological type of the lesion was squamous cell carcinoma and in 23 cases and adenosquamous cell carcinoma in 2 cases.
\end{abstract}

Correspondence: Hiroshige MIKAMO, Department of Obstetrics and Gynecology, School of Medicine, Gifu University 


\section{Collection and processing of specimens}

Immediately after total abdominal hysterectomy, samples were taken directly from inside solid uterine cervical cancers using a polyesterfiber swab (Falcon Applicator, Becton Dickinson, Cockeysville, U.S.A.) and suspended in $5 \mathrm{~mL}$ of an anaerobic buffer containing a reducing agent in a $\mathrm{CO}_{2}$-filled tube.

The composition of the anaerobic buffer was as follows; $\mathrm{KH}_{2} \mathrm{PO}_{4} 4.0 \mathrm{~g}, \mathrm{Na}_{2} \mathrm{HPO}_{4} 6.0 \mathrm{~g}$, Lcysteine $\cdot \mathrm{HCl} \cdot \mathrm{H}_{2} \mathrm{O} 1.0 \mathrm{~g}$, Tween 80 (Sigma) $1.0 \mathrm{~g}$, Agar $1.0 \mathrm{~g}$, Distilled water $1000 \mathrm{~mL} / \mathrm{pH}$. 7.2. All of the components were mixed together, and a solution was prepared by heating at $80^{\circ} \mathrm{C}$ for 30 minutes. After transferring $9 \mathrm{~mL}$ of the buffer to each of the test tubes, the air in the tubes was replaced with $\mathrm{CO}_{2}$, and the tubes were immediately sealed with a butyl rubber stopper. All tubes and solutions were sterilized in an autoclave at $115^{\circ} \mathrm{C}$ for 20 minutes.

After suspending the samples, the tubes were re-sealed under a continuous stream of commercial grade of carbon dioxide to drive air out. Exposure of the samples to atmospheric oxygen wass restricted to 5 minutes or less. Incubation was commenced immediately after the samples had been suspended in the solution.

Aliquots were aspirated through a butyl rubber stopper using a syringe and retained for subsequent quantitative culture.

The best sampling method is aspiration, but since it is impossible to take aspirated specimens in the case of uterine cervical cancer, we collected the specimens with swabs.

3. Quantitative bacteriologic assay

Serial dilutions of $10^{2}, 10^{4}$, and $10^{6}$ were prepared in anaerobic buffer. A $0.1 \mathrm{~mL}$ sample of each dilution was plated on each of 8 media.

For anaerobic organisms, Brucella HK (Hemin, Vitamin K1), RS (Rabbit, Sheep), blood agar (Kyokuto Pharmaceutical Industrial Co., Tokyo, Japan), PEA ( $\beta$-phenylethylalchol) laked Brucella HK blood agar (Kyokuto Pharmaceutical Industrial Co., Tokyo, Japan), PV (Paromomycin, Vancomycin), Brucella HK blood agar (Kyokuto Pharmaceutical Industrial Co., Tokyo, Japan) and Bacteroides bile esuculin agar (Kyokuto Pharmaceutical Industrial Co., Tokyo, Japan). These anaerobic agar plates were stored under anaerobic conditions prior to use.

The following media were employed for aerobic and facultative anaerobic isolates: blood agar (Becton Dickinson, Cockeysville, U.S.A.), chocolate agar (Becton Dickinson, Cockeysville, U.S.A.), MacConkey agar (Beton Dickinson, Cockeysville, U.S.A.), Staphylococcus selective agar (Nissui Pharmaceutical Industrial Co., Tokyo, Japan). After incubation, morphologically distinct colonies on the plates were subcultured onto respective blood agar plates and purified by standard microbiologic methods. Quantitative results are expressed as ranges and mean $\log _{10}$ of viable bacteria per swab.

4. Identification of isolates

All bacterial isolates were identified at the genus and species level. Anaerobic isolates were identified using the Rap ID ANA II identification system (Innovative Diagnostic System, Inc., Atlanta GA) combined with gas-liquid chromatography (GLC) to identify fatty acids produced during growth in PYG broth (Scott Laboratories, Rockville, MD). Isolates that were difficult to identify were subjected to technques described in the anaerobic laboratory manual ${ }^{2}$.

Microaerophilic and aerobic isolates were identified by standard identification schemata. Gardnerella vaginalis was identified using the API STREP identification system (API System S.A., Montalieu vercieu); Lactobacillus was identified at the genus level by GLC; members of the Enterobacteriaceae family were identified using the Enterotube II identification system (Becton Dickinson, Cockeysville, U.S.A); members of the Micrococcaceae family were identified using the API STAPH identification system (API System S.A., Montalieu vercieu); members of the genera Streptococcus and Enterococcus were identifjed by the API 


\section{STREP identification system.}

\section{Results}

The species of bacteria present in the sampling solution and the case numbers are shown in Table 1 .

Table 1 Bacteria detected inside solid uterine cervical cancers

\begin{tabular}{|c|c|c|c|c|c|c|c|c|c|c|c|c|c|c|c|c|c|c|c|c|c|c|c|c|c|c|c|}
\hline & \multicolumn{2}{|r|}{ Clinical stage(FIGO) } & \multicolumn{2}{|c|}{$\mathrm{O}$} & \multicolumn{4}{|c|}{ Ia } & \multicolumn{5}{|c|}{$\mathrm{Ib}$} & \multirow{2}{*}{$\frac{\mid \mathrm{IIa}}{12}$} & \multicolumn{10}{|c|}{ IIb } & \multicolumn{2}{|c|}{ IIIa } & \multirow{2}{*}{$\frac{\text { IVa }}{25}$} \\
\hline \multicolumn{2}{|c|}{ Bacteria } & Case Number & 1 & 2 & 3 & 4 & 5 & 6 & 7 & 8 & 9 & 10 & 11 & & 13 & 14 & 15 & 16 & 17 & 18 & 19 & 20 & 21 & 22 & 23 & 24 & \\
\hline \multirow{20}{*}{$\begin{array}{l}\mathrm{A} \\
\mathrm{E} \\
\mathrm{R} \\
\mathrm{O} \\
\mathrm{B} \\
\mathrm{E} \\
\mathrm{S}\end{array}$} & \multirow{8}{*}{$\begin{array}{l}\mathrm{G} \\
\mathrm{P} \\
\mathrm{C}\end{array}$} & S. epidermidis & & H & H & m & & & & & & & & & & & + & & & & & & + & & & & H \\
\hline & & S. aureus & & & & & & & & & + & + & & & + & + & + & & & & & & & & & H & \\
\hline & & S. haemolyticus & & & & & + & & & $H$ & & & & $H$ & & & & & H & & & + & + & & + & + & \\
\hline & & S. hominis & & $H$ & & & + & & H & & & & & & & & & + & & & m & & & & $H$ & & \\
\hline & & S. capitis & + & & & & & & & & & & & & & & & & & & & & & & & & \\
\hline & & S. xylosus & & & & & & & & & & & & & & & & & + & & & + & & & & & + \\
\hline & & S. auricularis & & & & & & + & & & & & & & & & & & & & + & & & + & & & \\
\hline & & S. sciuri & & & & & & & & & & & & & & & & + & & & & & & & & & \\
\hline & & S. agalactiae & & & & & & & & & & & m & & + & & & & H & & & + & + & & & m & + \\
\hline & & S. oralis & & & + & & & & & & & & & & & H & & & & & & & & & & & \\
\hline & & S. intermedius & & & & & & & H & & & & & & & & & & & \# & & & & H & & & \\
\hline & & G. morbillorum & & & & & & & & & & + & & & & & & + & & & & & & & & & \\
\hline & & E. faecalis & & & & & & & & & m & & & & m & + & & & & H & & & H & & & H & \\
\hline & & E. faecium & & & m & & & & & & & & H & & & & & & H & & & & & & & + & \\
\hline & & Corynebacterium spp. & & + & & & & & & + & & & & + & & & & & & & & & & & & & \\
\hline & $\underset{\mathrm{P}}{\mathrm{C}}$ & GPB & & & & & & & & & & & & & & & + & & & & & & & & & & \\
\hline & $\mathrm{B}$ & G. vaginalis & $\mathrm{H}$ & & & m & & m & & H & & & & & & H & m & & & m & $H$ & + & & m & m & & \\
\hline & & Lactobacillus spp. & + & & & & & $H$ & & H & & & + & + & & + & & & & & + & & & & + & & \\
\hline & G & E. cloacae & & & & & & & & & & & & + & & & & & & & & & & & & & \\
\hline & $\mathrm{B}$ & E. coli & & & H & H & & m & & & H & & H & $H$ & H & + & & & & + & + & & \pm & + & & + & \\
\hline \multirow{19}{*}{$\begin{array}{l}\mathrm{A} \\
\mathrm{N} \\
\mathrm{A} \\
\mathrm{E} \\
\mathrm{R} \\
\mathrm{O} \\
\mathrm{B} \\
\mathrm{E} \\
\mathrm{S}\end{array}$} & \multirow{6}{*}{$\begin{array}{l}\mathrm{G} \\
\mathrm{P} \\
\mathrm{C}\end{array}$} & P. anaerobius & & & & & & & & & & & & & & & & + & & & & & + & & & & + \\
\hline & & P. asaccharolyticus & & & & & & & & & & & & + & & & & & H & & & & & & & & \\
\hline & & P. magnus & & & + & & + & & & & & & & + & & & & & & & & & & & & & \\
\hline & & P. micros & & H & & & H & & $\mathrm{H}$ & & & + & & + & + & & & H & & & & & & $H$ & & & \\
\hline & & P. prevotii & & & & & & & & & + & & & & & & H & & & & & & & & & & \\
\hline & & P. tetradius & & & & & & & & & & & & & & & & & & + & & & & & H & & \\
\hline & \multirow{7}{*}{$\begin{array}{l}\mathrm{G} \\
\mathrm{P} \\
\mathrm{B}\end{array}$} & Bifidobacterium spp. & & & & H & & & & & + & & & & & & & & & & & & & $H$ & & & \\
\hline & & C. innocuum & & & & & & & & & & & & & & & & & & & & & & + & & & \\
\hline & & P. acnes & H & & + & & & & & & & & & & & & & & & & & & & & m & + & \\
\hline & & B. fragilis & & & & & H & & $\mathrm{H}$ & & & & & & & & + & & & & + & & & & & m & \\
\hline & & B. distasonis & & & & & & & & m & & H & & $m$ & H & m & & H & & & & m & + & & $\mathrm{H}$ & & \\
\hline & & B. ovatus & & & & & & & & & & & + & + & & & & & & & & & & & & & \\
\hline & & B. thetaiotaomicron & & & & & & m & & & & & & & & & & & & & m & & + & & & & \\
\hline & $\mathrm{G}$ & P. bivia & & & & & & & & & & & & & H & H & & + & & & & H & & $H$ & & & 册 \\
\hline & $\mathrm{B}$ & P. disiens & & & & \# & & & & & & & & & & & & & \# & & & & + & & & & + \\
\hline & & P. oralis & & & & & & & & & & & & & & & + & & & & & & & + & & & \\
\hline & & P. intermedia & & & & & & & & & & & & & & & & & & H & & & & & & & \\
\hline & & Capnocytophaga sp. & & & & & & & & & & & & & & & & & & & & & & & $H$ & & \\
\hline & & Wolinella spp. & & & & & & & + & & & & & & & & & & & & & H & & & & & \\
\hline & & Total & 4 & 4 & 6 & 5 & 5 & 5 & 5 & 5 & 5 & 4 & 5 & 10 & 7 & 8 & 7 & 7 & 6 & 6 & 7 & 7 & 9 & 9 & 8 & 8 & 6 \\
\hline
\end{tabular}

FIGO : International Federation of Gynecology and Obstetrics 
Both aerobic and anaerobic bacteria were detected in all subjects.

The average number of species isolated from inside solid uterine cervical cancers was 6.3.

The following aerobic bacteria were detected: Staphylococcus epidermidis in six cases (24.0\%), Staphylococcus aureus in six cases (24.0\%), Staphylococcus haemolyticus in eight cases (32.0\%), Staphylococcus hominis in six cases (24.0\%), Staphylococcus capitis in one case (4.0\%), Staphylococcus xylosus in three cases (12.0\%), Staphylococcus auricularis in three cases (12.0\%), Staphylococcus sciuri in one case (4.0\%), Streptococcus agalactiae in seven cases (28.0\%), Streptococcus oralis in two cases (8.0\%) Streptococcus intermedius in three cases (12.0\%), Gemella morbillorum in two cases (8.0\%), Enterococcus faecalis in six cases (24.0\%), Enterococcus faecium in four cases (16.0\%), Corynebacterium spp. in three cases (12.0\%), $G$. vaginalis in 11 cases (44.0\%), Lactobacillus spp. in eight cases (32.0\%), a Gram-positive bacillus in one case (4.0\%), Enterobacter cloacae in one case (4.0\%) and Escherichia coli in 13 cases (52.0\%).

Among these aerobic bacteria, the isolation rates for S. haemolyticus, S. agalactiae, G. vaginalis, Lactobacillus spp., E. coli was rather high (greater than $25 \%$ ). The bacterial counts of $C$. vaginalis, $S$. agalactiae and $E$. coli were greater than those of other species.

The following anaerobic bacteria were detected: Peptostreptococcus anaerobius in three cases (12.0\%), Peptostreptococcus asaccharolyticus in two cases (8.0\%), Peptostreptococcus magnus in three cases (12.0\%), Peptostreptococcus micros in eight cases (32.0\%), Peptostreptococcus prevotii in two cases (8. (1\%), Peptostreptococcus tetradius in two cases (8.0\%), Bifidobacterium spp. in three cases (12.0\%), Clostridium innocuum in one case (4.0\%), Propionibacterium acnes in four cases (16.0\%), Bacteroides fragilis in five cases (20.0\%), Bacteroides distasonis in nine cases (36.0\%), Bacteroides ovatus in two cases (8.0\%), Bacteroides thetaiotaomicron in three cases (12.0\%), Prevotella bivia in six cases (24.0\%), Prevotella disiens in four cases (16.0\%), Prevotella oralis in two cases (8.0\%), Prevotella intermedia in one case (4.0\%), Capnocytophaga sp. in one case (4.0\%) and Wolinella spp. in two cases (8.0\%).

All 25 subjects had one or more species of anaerobic bacteria. Five species of bacteria were detected in two cases, four species in three cases, three species in six cases, two species in nine cases, and only one species in five cases. Both aerobic and anaerobic bacteria were detected in every case.

$P$. micros, $B$. distasonis and $P$. bivia were detected more often than other anaerobic bacteria.

\section{Discussion}

The bacterial flora in the genital tract of normal women are thought to be influenced by various factors, such as hormonal factors, aging, etc. There was little relationship between the bacterial flora of cervical cancer and patient age, suggesting that estrogen did not have much effect.

As the stage of cervical cancer became more advanced, S. agalactiae, E. coli, G. vaginalis, B. distasonis and $P$. bivia were detected at higher counts than other bacteria detected from uterine cervical cancers.

Bacteria detected inside solid uterine cervical cancers may produce carcinogens or growth factors ${ }^{4,5,6,7,8,9,10)}$.

Mixed aerobic and anaerobic abnormal bacterial flora were detected in all of the patients with uterine cervical cancer. It appears that the presence of uterine cervical cancer affected the growth of the bacteria, or that mixed abnormal bacterial flora influenced the onset and growth of uterine cervical cancer.

\section{References}

1) Ito, K., Tamaya, T., Watanabe, K. \& Ueno, K.: Intravaginal bacterial flora in patients with cervical cancer especially Gardnerella vaginalis. Acta Obst Gynaec Jpn 42(11): 1551-1555, 1990.

2) Holdeman, L.V.E.P., Cato, E.P. \& Moore, W.E.C.: Anaerobe laboratory manual. 4th edition. Anae: obe Laboratory. Virginia, 1977.

3) Ralt, D., Wishnok, J.S., Fitts, R. \& Tannebaum, S.R.: Bacterial catalysis of nitrosation: Involvemen of nar operon of 
Escherichia coli. J Bacteriol, 359-364, 1988.

4) Calmels, S., Ohshima, H., Vincent, P., Gounot, A.M. \& Bartsch, H.: Screening of microorganisms for kinetic studies on nitrosamine formation from secondary amines by E. coli strains. Carcinogenesis, 6(6): 911-915, 1985.

5) Calmels, S., Ohshima, H., Rosenkrantz, H., MacCoy, E. \& Bartsch, H.: Biochemical studies on the catalysis of nitrosation by bacteria. Caricnogenesis, 8(8): 1085-1088, 1987.

6) Pavic, N.: Is there a local production of nitrosamines by the vaginal microflora in anaerobic vaginosis/ trichomoniasis?. Med Hypoth, 15: 433-436, 1984.

7) Kishishita, M., Yanase, S. \& Ito, Y.: Activation of Epstein-Barr virus expression in human lymphoblastoid P3HR-1 and Raji cells with propionic acid and with culture fluids of propionic acid-producing anaerobes. Cancer Lett, 16: $117-120,1982$.

8) Leder, A. \& Leder, P.: Butyric acid, a potent inducer of erythroid differentiation in cultured erythroleucemic cells. Cells, 5: 319, 1975.

9) Hill, J.M.: Bacteria and human carcinogenesis. Bacteria and cancer, Academic Press, 27-47, 1982.

10) Imai, A., Matsunami, K., Ohno, T. \& Tamaya, T.: Enhancement of growth-promoting activity in extract from uterine cancers by protein kinase-C in human endometrial fibroblasts. Gynecol Obstet Invest, 33: 109-113, 1992.

\section{子宮頸癌固形腫瘍内部の細菌学的検討

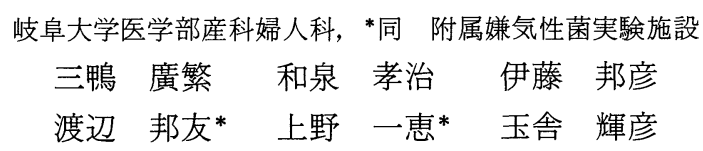

子宮頸癌患者 25 名 ( 0 期 2 例, Ia 期 4 例, Ib 期 5 例, IIa 期 1 例, IIb 期 10 例, IIIa 期 2 例, IVa 期 1 例）の固形腫瘍内部の細菌学的検討を行った. 全症例で, 好気性菌と嫌気性菌が混在していた。 1 症例あたりの平均分離株数は，6.3株であった。 分離された細菌は，好気性菌では，Staphylococcus haemolyticus, Streptococcus agalactiae, Escherichia coli, Gardnerella vaginalis $か ゙$, 嫌気性
菌では, Peptostreptococcus micros, Bacteroides distasonis, Prevotella bivia が優位を占めていた。 特に, 子宮頸癌進行期の進展とともに, $G$. vaginalis, B. distasonis, P. bivia などの細菌が他 の細菌に比較して高率に検出された.

以上より, G. vaginalis, B. distasonis, P. bivia などの細菌が, 子宮頸癌の発生や進行に関与して いる可能性が示唆された。 